\title{
Management accounting of agricultural land fertility in the Kursk region of the Russian Federation
}

\author{
T.M. Vorozheykina ${ }^{1, *}$, and T.Y. Bobovnikova ${ }^{1}$ \\ ${ }^{1}$ Russian State Agrarian University - Moscow Timiryazev Agricultural Academy, Moscow, Russia
}

\begin{abstract}
In the conditions of competition and limited resources, sources of income, lean production has recently been developing and, at the same time, lean management accounting is developing. Agriculture in the Russian Federation is characterized by a slow movement of capital, high dependence on natural and climatic conditions, low economic manoeuvrability, and the predominance of collective and shared ownership of land. Agricultural production uses natural factors for the cultivation of biological assets and the production of agricultural products free of charge: the natural fertility of agricultural land, natural pastures for grazing, solar and wind energy, etc. Chernozem lands are the most important fertile lands in the world. $40 \%$ of the most fertile chernozem lands are concentrated in Russia, in five regions, one of which is the Kursk region. The processes of land degradation are mainly inherent in agricultural land, or rather arable land. The economic state of agriculture in Russia does not allow for the full implementation of measures to preserve soil fertility, and even more so to take them into account. The purpose of the study is to study the state of agricultural land fertility from the point of view of management accounting. In accordance with the set goal, the following tasks were identified: fertility was identified as an object of management accounting for agricultural land, and the indicators that should be taken into account were determined. The novelty of the research conducted by the authors consists in the development of management accounting that is appropriate for long-term planning of measures for the effective use of agricultural land. In the course of the study, general scientific and special research methods were used on the basis of systematization of theoretical and practical material. The natural fertility of agricultural land is not taken into account anywhere in the costs of agricultural production, as well as its cost price, is not reflected in the accounting. Currently, there is no data collection system that covers all aspects of agricultural land and should serve as a basis for improving the agricultural sector. Results: the analysis of land resources in Russia, in the Kursk region is presented; the comparative characteristics of land in accordance with IAS and AR 6/01 are shown. It is proposed to keep records of soil fertility, to allocate "agricultural land" in the reporting, to distribute subsidies depending on changes in the level of fertility, but taking into account zoning.
\end{abstract}

\section{Introduction}

Land resources play a crucial role in the development of the state, the solution of food and national security. Agricultural land is the most important natural resource that has a unique feature-fertility. For the effective and harmonious development of the Russian Federation and agricultural lands, it is necessary to understand and understand the actions that contribute to the formation of the desired future, taking into account the socioeconomic interests of all stakeholders. The influence of the features of agribusiness processes on the accounting and analytical support of the management of agricultural land fertility is insufficiently studied. Agricultural land is the main means of production, so it is important to ensure accurate accounting of land and its fertility.

\section{Methods}

In this paper, using control procedures (methods and techniques), various aspects of accounting for the fertility of agricultural land are analyzed, and the main areas of research in the field of management accounting of land resources are identified. As part of the integrated approach, the methods of observation, comparison, grouping, and the balance method were also used. The information base of the study was the official statistics of Russia and the Kursk region [1,2].

\section{Results}

In the Russian Federation a significant part of agricultural land was in state and municipal ownership $254,126.5$ thousand hectares or $66.6 \%$ of the category of land, owned by citizens -106630.9 thousand hectares

\footnotetext{
* Corresponding author: vorozheykina@gmail.com
} 
Table 1. Fixed assets - Land in accordance with AR 6/01 and IAS 16 " Fixed assets».

\begin{tabular}{|c|c|}
\hline \multicolumn{2}{|r|}{ Definition } \\
\hline AR 6/01 & None \\
\hline IAS 16 & $\begin{array}{l}\text { Tangible assets that are intended for use in the production or delivery of goods and services, for } \\
\text { leasing or for administrative purposes }\end{array}$ \\
\hline \multicolumn{2}{|r|}{ Objects of fixed assets } \\
\hline AR 6/01 & $\begin{array}{l}\text { buildings, structures, working and power machines and equipment, measuring and regulating devices } \\
\text { and devices, computer equipment, vehicles, tools, production and household inventory and accessories, } \\
\text { working, productive and breeding cattle, perennial plantings, on-farm roads and other relevant objects. } \\
\text { Fixed assets also include: capital investments for fundamental land improvement (drainage, irrigation } \\
\text { and other land reclamation works); capital investments in leased fixed assets; land plots, natural } \\
\text { resources (water, subsoil and other natural resources). }\end{array}$ \\
\hline IAS 16 & $\begin{array}{l}\text { land; land and buildings; machinery and equipment; watercraft; aircraft; motor vehicles; furniture and } \\
\text { embedded engineering equipment; office equipment; fruit crops. }\end{array}$ \\
\hline \multicolumn{2}{|r|}{ Accounting unit } \\
\hline AR 6/01 & Inventory item \\
\hline IAS 16 & Doesn't define \\
\hline \multicolumn{2}{|r|}{ amortization } \\
\hline AR 6/01 & $\begin{array}{l}\text { Items of property, plant and equipment whose consumer properties do not change over time are not } \\
\text { subject to depreciation (land plots; natural resources management objects; objects classified as } \\
\text { museum objects and museum collections, etc.). }\end{array}$ \\
\hline IAS 16 & $\begin{array}{l}\text { land plots are not depreciated except for } \\
\text { - parts of the land plot (the initial cost of which includes the costs of dismantling, removing fixed } \\
\text { assets and restoring the environment on this site), } \\
\text { - a land plot with a limited useful life }\end{array}$ \\
\hline \multicolumn{2}{|r|}{ Accounting for the amount of additional assessment } \\
\hline AR 6/01 & s accounted for in additional capital (account 83) \\
\hline IAS 16 & is accounted for as other comprehensive income \\
\hline \multicolumn{2}{|r|}{ Accounting for the markdown amount } \\
\hline AR 6/01 & is recognized in other expenses (account 91) \\
\hline IAS 16 & is recognized in profit or loss \\
\hline
\end{tabular}

(27.9\%), owned by legal entities - 20915.6 thousand hectares $(5.5 \%)$ by January 1,2020 . The share of agricultural land accounts for $95.9 \%$ among all the land plots in Russia that are privately owned. Land plots classified as agricultural land and owned by citizens for $75.3 \%$ consist of land shares.

The Kursk Region is part of the Central Chernozem Region. (CDR). The Central Chernozem Region includes five regions: Kursk, Belgorod, Voronezh, Lipetsk and Tambov $[3,4]$. The Central Chernozem region has a unique natural resource - powerful chernozem soils with a high supply of humus. the most valuable for agricultural production is arable land. The share of arable land in the total area of agricultural land in the regions of the Central Chernozem region was as follows: Belgorod region-77\%; Voronezh region-74.5\%; Kursk region $-79.7 \%$, Lipetsk region- $79.5 \%$, Tambov region-
$78 \%$. On average, the level of agricultural land development in the Central Chernozem Region is $77.7 \%$, and in the Central Federal District - 72\%.

In the Kursk region, out of 2999.7 thousand hectares, 1306.3 thousand hectares are owned by citizens, and 623.9 thousand hectares are owned by legal entities..

In accordance with Russian and international legislation, land is the main asset (table 1).

In accordance with IAS 16 "Fixed Assets", paragraph 58 states that land plots have an unlimited useful life and are not subject to depreciation. In the system of accounting, management accounting, no records are made on the accounting of land fertility, although fertility may deteriorate and increase.

The complex indicator of soil fertility for the districts of the Kursk region ranges from 55 to 83, and for farms from 47 to 100 (Table 2).

Table 2. Soil fertility of the Kursk region [5].

\begin{tabular}{|l|l|l|}
\hline Zoning of the area & Charachteristics & $\begin{array}{l}\text { Coefficient of } \\
\text { soil fertility }\end{array}$ \\
\hline Low soil fertility (55-65) & $\begin{array}{l}\text { Low-humus soils with acidic reaction } \\
\text { Rylsk, Khomutovka, Konyshevka, Lgov, Kurchatov, Fatezh, Dmitriev- } \\
\text { Lgovsky, Zheleznogorsk }\end{array}$ & 1 \\
\hline $\begin{array}{l}\text { Medium soil fertility (66- } \\
75)\end{array}$ & $\begin{array}{l}\text { Glushkovo, Korenevo, Sudzha, Belaya, Zolotukhino, Shchigry, } \\
\text { Cheremisinovo, Tim, Kshen, Kastornoye, Bolshesoldatsky, Kursky district }\end{array}$ & 1.2 \\
\hline $\begin{array}{l}\text { High soil fertility (76- } \\
85)=\text { high production } \\
\text { potential }\end{array}$ & $\begin{array}{l}\text { Dominated by fertile soils } \\
\text { Solntsevsky and Medvensky P 81-81, Oboyan, Pristen, Manturovo, } \\
\text { Gorshechnoe }\end{array}$ & 1.4 \\
\hline
\end{tabular}


Table 3. System of accounting for agricultural land (Author's methodology).

\begin{tabular}{|c|c|}
\hline $\begin{array}{l}\text { Financial } \\
\text { accounting }\end{array}$ & $\begin{array}{l}\text { The purpose is to generate information about quantitative, qualitative and cost measures of land } \\
\text { owned, used and leased on the basis of data from primary documents and registers of analytical and } \\
\text { synthetic accounting } \\
\text { Providing information to external users, mainly in monetary terms. } \\
\text { Accounting (financial statements), forms of the agroindustrial complex }\end{array}$ \\
\hline Tax Accounting & $\begin{array}{l}\text { The formation of land tax reports based on financial and management accounting data } \\
\text { The information is closed to external users. } \\
\text { Land tax declaration }\end{array}$ \\
\hline $\begin{array}{l}\text { Management } \\
\text { accounting }\end{array}$ & $\begin{array}{l}\text { The main purpose of management accounting is the formation of information for the calculation of } \\
\text { indicators of the efficiency of the use of agricultural land, taking into account the level and dynamics } \\
\text { of the fertility of agricultural land. } \\
\text { Information - quantity and quality. } \\
\text { Closed information: balance of nutrient removal, agro-economic crop rotation, lease term. }\end{array}$ \\
\hline
\end{tabular}

Using this assessment of the fertility of soil resources, it is possible to plan priority activities to increase the fertility of arable land in the Kursk region, as well as to subsidize it. Currently, the level of soil fertility and its dynamics should be one of the criteria for the distribution of subsidies to support the income of commodity producers in the field of crop production between the subjects of the Russian Federation.

\section{Discussion}

Accounting for agricultural land occupies a certain place in accounting (financial), management and tax accounting [6-11].

Many countries have their own peculiarities in land accounting, which consist in additional classification by accounts. So, in Austria, Germany, the "Land without buildings" is reflected. In Finland and Portugal, accounting is carried out under the article "Land and natural deposits". In Belgium, Denmark, Great Britain, and Ireland, the reflection occurs under the article "Land and buildings".

Some features of land resources are defined by IAS and GAAP. It is characteristic that agricultural land is not allocated separately in IAS. In accordance with GAAP standards, the value of land used for agricultural purposes is subject to depreciation. This is because the land loses its fertility over time. In accordance with IAS, if the land has a limited useful life (let's define this term - crop rotation), then it should be considered as an amortised asset.

If the land is acquired for the purpose of generating future income from an increase in its price, then the name of the investment property takes place and it is also revalued as property, plant and equipment (accounted for in accordance with IAS 40 "Investment Property").

Mechanisms of land management accounting should guide agricultural organizations to create an effective system of accounting for agricultural land (Table 3).

Every owner should know the transformation of the quality indicators of their land resources. Adequate reflection of operations will help to improve the efficiency of agricultural production.

Taking into account the above, we believe that accounting regulation should promote compliance with public and private interests in the use of land, since it is necessary to preserve the productivity of agricultural land. The reason for the use of agricultural land, which leads to the deterioration of soil fertility, especially in large agricultural organizations, is not the lack of necessary knowledge and skills for the rational use of land, but economic benefits.

The market for agricultural land in Russia has not yet developed. The cadastre is a source of information when assessing land resources for accounting purposes. We believe that this information, which contains information about large landowners, should be freely available to the indigenous people of a particular region

Due to the insufficient development of the regulatory framework in the field of land accounting, land plots are recorded only in quantitative accounting. The allocation of agricultural land in the balance sheet actualizes the problem of effective use of land resources

At the same time, in many regions of the Russian Federation, including the Kursk region, subsidies do not depend on changes in the level of soil fertility, taking into account zoning.

At the end of the lease term, it is advisable to redistribute land in favor of farms that comply with their ecological condition. Payments for improving the quality of land are one of the most powerful levers of influence that allows you to maintain soil fertility at the existing level.

\section{Conclusion}

Any land asset can be evaluated in two ways: either from the perspective of the past, that is, the costs invested in the production of the estimated asset, or from the perspective of the future.

Currently, economic analysis does not allow us to take into account the natural ecosystem, especially the properties of the main resource - agricultural land. The study of the natural factor (fertility) will minimize or prevent harmful effects on the production process and develop a number of measures aimed at eliminating it. 


\section{References}

1. M.V. Vladyka, O.V. Vaganova, S.A. Kucheryavenko, N.I. Bykanova, Analysis of efficiency indicators of a macro region's economy (on the example of the Central Federal District), Social Sciences (Pakistan), 11 (15), 3728-3733 (2016)

2. O.V. Vaganova, A.B. Titov, N.E. Solovjeva, N.I. Bykanova, Influence of the Sanctions Regime on the Regional Innovation System Formation: Evidence from Belgorod [Electronic resource], International Journal of Economic Perspectives (ISSN:1307-1637), 11 (3), (September 2017) Available at: http://www.econsociety.org/ijep_contents 11.3.php\#

3. T. Bobovnikova, T. Vorozheykina, Accounting for the fertility of land resources as a factor in the sustainable development of the Kursk region, IOP Conf. Ser. Earth and Environmental Sci., 395 (1), 012029 (2019)

4. T.Y. Bobovnikova, T.M. Vorozheykina, Rationalization of Accounting (Financial) Statements of Land Assets in Agricultural Holdings of the Russian Federation, Proceedings of the Russian Conference on Digital Economy and Knowledge Management (RuDEcK 2020), Part of series AEBMR, 148, 76-80 ISSN: 23525428 ISBN: 978-94-6252-997-7 DOI: 10.2991/aebmr.k.200730.014

5. Actual problems of soil science, ecology and agriculture, Collection of reports of the scientific and practical conference of the Kursk branch of the IPO "Society of Soil Scientists named after V.V. Dokuchaev" (Kursk; FGBNU VNIIZiZPE, 2014, 125)

6. T. Skryl, V. Osipov, T. Vorozheikina, On the way to ecological agriculture: Decision-making process in agrarian state policy, Conference Series: Earth and Environmental Science. Sci., 274, 012066 DOI: $10.1088 / 1755$ $1315 / 274 / 1 / 01206$

7. D.S. Strebkov, Advanced tendencies in development of photovoltaic cells for power engineering, Thermal Engineer, English translation of Teploenergetika, 62 (1), 7-13 (2015)

8. D.A. Cauich-López, , L.F. Barrera Payan, A.M.N. Abdelhalim, E. Socolova, A.A. Sinitsyn, A.A., I.G. Akhmetova, Small-scale steam generation from local solid waste, International Journal of Civil Engineering and Technology, 10(2), 2118-2129 (2019).

9. N. Politaeva, Y. Smyatskaya, R. Al Afif, C. Pfeifer, L. Mukhametova, Development of Full-Cycle Utilization of Chlorella sorokiniana Microalgae Biomass for Environmental and Food Purposes, Energies, 13(10)2, 2648 (2020)

10. N. Ponomareva, A. Zvereva, E. Golubtsova, S. Ilyashenko, G. Ivanov, Certain economic instruments as a factor of realizing the potential of using alternative energy sources in russia, E3S Web of Conferences, 124, (2019) doi:10.1051/e3sconf/201912405066 Retrieved from www.scopus.com

11. S. Ilyashenko, M. Belyakova, A. Zvereva, Possibilities of application of digital tools by the organizations of sphere of services and trade in the Russian Federation, IOP Conference Series: Materials Science and Engineering, 940(1), 012059, (2020) 